\title{
Psychoanalytic Literary Criticism: Using Holland's DEFT Model as a Reader Response Tool in the Language Classroom
}

\author{
Lubie Grujicic-Alatriste ${ }^{1}$ \\ City University of New York, College of Technology
}

\begin{abstract}
Language students tend to struggle with literature because they find psychological and socio-cultural implications embedded in literary texts difficult to understand and discuss (Kramsch, 1996). This paper suggests that psychoanalytic literary criticism may offer a reading framework that could mitigate the struggle and allow for a deeper level of personal and social exploration of literary works. The DEFT model (Defense, Expectations, Fantasy and Transformation), as one type of reader-response approach to reading that draws on the psychoanalytic framework, might make the reading of literature easier because of its potential to offer to students strategies for finding a point of entry into the text. According to DEFT, the inability to find a point of entry into a new reading may be one of the reasons for finding a literary piece difficult, for 'disliking' or outright rejecting it. This qualitative study shows how the DEFT approach, originally created for native speakers but thus far little researched in relationship to non-native speakers, can be used to facilitate the reading of literary works in a language course.
\end{abstract}

\section{Introduction}

Literature used to dominate language teaching in the first half of the twentieth century. With the development of a stronger focus on linguistics in language teaching, the role of literature was seriously challenged (e.g., Topping, 1968). Concerns were voiced that literary language could be difficult for all readers, but even more so for non-native speakers due to non-standard language use, colloquialisms and 'loose dialogue' (Topping, 1968). Thus, it was suggested that literature be used less frequently as a tool for teaching language.

Since then, the place of literature in language learning has been debated in both second and foreign language teaching (e.g., Carter \& Burton, 1982; Carter \& Long, 1991; Hill, 1986; Kramsch, 1996; Povey, 1967; Spack, 1985; Widdowson, 1983). More recently, though, useful pedagogical resources for teachers have been developed and used in English as foreign language teaching (e.g., Collie \& Slater, 2002; Lazar, 2000).

The theoretical issues dominating the debate on the relationship between language learning and literature translated into research studies that generally focused on well established reading variables such as word recognition, vocabulary gains, language

${ }^{1}$ Correspondence concerning this article should be addressed to Dr. Lubie GrujicicAlatriste. E-mail: lalatriste@citytech.cuny.edu 
knowledge (grammar and syntax), text structure, reading strategies, motivation, recall, and comprehension (Grabe, 2004). Reader-response approaches to reading literature have not been prominent in second language research studies. While first language reading research boasts a number of studies examining the role of reader response methods (e.g., Sadoski et.al., 1988), and foreign language research (in USA contexts) examines reader response methods such as reading logs and journals (e.g., Redmann, 2005), second language reading research remains fairly silent on this topic. There may be a few reasons for this silence.

One reason is the current predominance of non-fictional prose as basis for multiple choice reading tests and a growing focus on assessment and discipline-based reading and writing in many academic English classes in the USA educational contexts. Second, some of the anxieties about literature persist. For example, Kramsch's (1996) finding that non-native readers tend to approach literary works with trepidation because they often find short stories or novels difficult to understand or discuss is still echoed by many today. Some teaching methodologies may also have contributed to the feeling of trepidation on the part of the learners. For example, discussing literary works in the classroom by calling on students to analyze the readings in a whole class format could be highly intimidating and anxiety-ridden. Also, the teacher's expectations for students to be able to 'instantly' upon reading a story explain complex psychological and socio-cultural issues raised in literary works, or connect them to their own realities, may be a cause for discomfort to some language learners (Kramsch, 1996).

Many of these views, though relevant, are somewhat overstated (Spack, 1985; Widdowson, 1983). Students struggle with literature in part because they are asked to explicate complex texts or to analyze them within more formalist traditions that place emphasis on the view that the core meaning is embedded in the text and needs to be 'found.' Such teaching approaches do not recognize the role of the reader as a meaning maker in this process. However, using reading approaches that recognize the reader as a central participant in interpreting the text and author may liberate both the learners and the classroom by facilitating the process of tapping into the text on a personal level first. So, perhaps the issue is not so much about literary language being too difficult and beyond the capacity of language learners to comprehend it, but rather about finding a reading approach that is most relevant to non-native speakers' reading needs.

Thus, what students need is support with both language and reading processes in order to be able to read, understand and enjoy literature in a second language. One way to help them is to offer "reading tools" or specific responding strategies in order to find a way to initially engage with a text and, during a multi-stage reading process, gain higher levels of both comprehension of the text and recognition of its personal, social and world relevance.

This qualitative study describes a reading tool called the DEFT (Defense, Expectations, Fantasy and Transformation), originally created by Norman Holland (1975), using psychoanalytic criticism as its principal framework. It views reading as an active process lived through during the relationship between a reader and a text (Rosenblatt, 1968). The questions this study set out to answer were: Can the DEFT be used with non-native speakers of English in the same way as with native speakers? Will the DEFT make finding a point of entry easier for non-native speakers? The research findings show that the DEFT model is a valuable tool for discovering a point of entry into the text and also 
for maintaining a more intense reader engagement with the text. The reading tool discussed in this study allows for gradual development of textual and thematic understanding and personal interpretations utilizing multiple readings, written responses and discussions that are low risk and student centered. Low risk is particularly important for language learners as it brings learning anxieties down and allows for more language intake and processing, and generally more successful learning (Ellis, 1985).

This article presents two students' pathways to a higher level of comprehension of psychological and socio-cultural issues in two short stories by American authors: "Happy" by Joyce Carol Oates and "The Story of an Hour" by Kate Chopin. The twomonth process involved multiple readings of the stories and recordings of responses in the reading logs (layering), with minimal 'intrusion' from the teacher, and no evaluative feedback. The teacher held class discussions and facilitated pair and group work by guiding students in the use of the DEFT model, but was doing so without direct teaching of the model.

Although this study applies a model of analysis that was originally created for native speakers of English to non-native speaker responses, its main focus is not second language acquisition (SLA) but the process of making meaning while reading and responding to literature. Vocabulary featured in the analysis as a starting point for DEFT elements, but language was not examined in terms of proficiency gains, vocabulary knowledge, or recall.

\section{Theoretical overview}

This study is framed within psychoanalytic reader response criticism for two main reasons: a) its emphasis on the central role of individual responses in the reading processes, and b) its concept of the need to find a point of entry into the text (Holland, 1975) - something all readers, particularly language learners, might need in order to more deeply engage with the text. Holland's research is broadly used as a base for the analysis of student responses. Thus, a brief overview of pertinent studies conducted by Holland is provided here, and relevant references are made to the theoretical works of Freud.

Holland started his work on literary criticism by experimenting with a number of psychoanalytic concepts and applying them to different readers' responses while reading literature $(1975 ; 1985 ; 1990)$. His early works evidence a fundamental belief that reading is a deeply personal, emotional and psychological process during which the reader and the text interact to create meaning. As he contends, "It is impossible to subtract the subjective elements in a reading from the objective, for each helps create the other [through] each reader's characteristic psychological process" (1990, p. 40). This process allows for textual meaning to be created through weaving done by the author and the reader. In short, reading is, in many of its aspects, a psychological process - a view embraced in this study.

Psychoanalytic criticism in literature can be traced back to the works of Freud (Meisel, 1981). Literary criticism borrowed key elements from classical Freudian psychology in an attempt to gain insights into reading processes and the role of personal and individual - the psychological - in the interpretations of literary works. Both 'Id' and 'Ego' psychology play a role in reader response interpretations. Classical Freudian Idpsychology considers sexual instincts as the determining force in an individual's life. In 
line with this concept, art, and by extension literature, is seen as the secret embodiment of its creator's unconscious desires (Wright, 1984, p. 37). According to Id-psychology, authors - when creating works of art - express their childhood experiences and innermost, secrete desires. Ego-psychology counters the idea that all art is a product of infantile desires. Rather, it claims that authors take infantile material and transform it into works that are publicly shareable and acceptable (Wright, 1984, p. 57). The conscious ego-instincts, concerned with self-preservation and the need to relate to others, are in conflict with the 'id' or the energies of the unconscious and the sexual instincts. Within ego-psychological criticism, a text is a shared, wish-fulfilling fantasy of both the reader and the author. In other words, in the area of literary criticism ego-psychology highlights the maintenance of identity through transformation of private fantasy that can be publicly shareable, whereas the Id-psychology privileges the maintenance of private fantasy and infantile desires, which are not publicly shareable.

It is the notion of private fantasy that Holland began to explore in the reading responses of his students. He realized that literary contexts have the potential to bring out a reader's fantasies and secret wishes precisely because such reading frameworks can make those fantasies and wishes more socially acceptable. Thus, the text becomes a place where the author and the reader collide around the core-fantasy shared by both. This is a major premise that allowed for building the DEFT model and later on applying it in teaching.

In his very early work "The Dynamics of Literary Criticism" (1968) Holland examined fantasy, wish-fulfilling and daydreaming phenomena. He created a dictionary of fantasy based on the stages of child development, as given in psychoanalysis: oral, anal, urethral, phallic, oedipal, latent, and genital. Holland began the analysis of a number of literary works by first listing vocabulary and literary expressions that could reflect each of the seven stages of child development. For example, words that relate to dirt or mess would be considered part of the 'anal' stage, food tasting or eating would be considered part of the 'oral' stage, whereas wetness would be considered urethral. Holland attempted to show that the world of adulthood is tightly connected with one's early childhood development, and that childhood fantasies tend to persist in adult works of art--and by extension in literature.

Fantasy and defense were the main tools in conducting an in-depth analysis of reader responses in his seminal work, "Five Readers Reading" (Holland, 1975). For his analysis, Holland adopted Freud's triad of character traits: parsimony, orderliness and obstinacy (Meisel, 1981). Using the short story "A Rose for Emily" by William Faulkner, Holland conducted exploratory interviews with five students in order to discover patters in students' characters and personalities that could lead him to insights into the way the mind works while one is reading literature. Holland painstakingly examined vocabulary his five student readers used when referring to the story, plot, and characters' actions. He also recorded students' free associations and personal stories they brought into the discussion of the short story. His study emphasized the idea that reading literature and talking about literature is not about the 'right' responses to the teacher's questions, but rather how responding can help a student connect to the story, or to her/his inner and outer reality. It is this aspect of Holland's research that was of particular interest in the present study. The following ideas put forward by Holland (1975) are relevant here: 
The stories do not mean in and of themselves. They do not fantasy, or defend, or adapt, or transform. People do these things, using stories as the occasion for a certain theme, fantasy, or transformation. The problem then becomes understanding, not the story in formal isolation, but the story in relation to somebody's mind. Not a mind hypothesized, hypostatized, assumed, positioned, or simply guessed at - but real minds in real people (p. 39).

Holland's extensive research resulted in the formation of the DEFT model, which stands for defense, expectations, fantasy and transformation. Within the model, the reading transaction is viewed as consisting of four fundamental steps: the reader's initial approach to the text (expectations), her/his being selective in what $\mathrm{s} /$ he takes in (mode of defense), her/his projection of wish-fulfillment (fantasy), and her/his translation of fantasies into themes (transformation). The idea of defense is borrowed from psychoanalysis to mean "the actions of ego which refuses to accept what it cannot tolerate" (Holland, 1975, p. 22). Defense, in this context, is directly related to the "liking or disliking' of the text and the ability of the reader to either be 'absorbed' in the text (taken out of oneself and merged with the characters and the happenings in the story), or left "flat" by the same. The story's act of meaning is adaptive because "meaning transforms primitive fantasies toward social, moral, and intellectual themes" (Holland, 1968 , p. 105). Defense, which is unconscious, is activated automatically when any kind of threat or danger appears in our lives. People try to modify their fears and fantasies according to their own perceptual matrices so that they can tolerate them and adapt to them. In Holland's words (1968), dream and fantasy are important elements in the reading process because, as he explains: "A literary work dreams a dream for us. It embodies and evokes in us a central fantasy; then it manages and controls that fantasy by devices that, were they in mind, we could call defenses, but being on a page, we call form" (p. 75).

\section{The role of DEFT in the present study}

Both defense and fantasy are considered core concepts in the present study. However, it should be noted that although this study applied Holland's DEFT model, it did not use the seven pre-set vocabulary stages from his original study of five readers reading a text. Instead, the responses were generated based on the readers' self-selecting attractive, interesting or otherwise important parts of the short stories they were reading.

Anecdotal evidence tells us that all readers tend to initially respond to literature by the level of liking it (or disliking it, as the case may be). Within the DEFT framework this translates into the idea that readers experience defense when faced with literary selections they 'dislike' because they actually cannot 'enter' the text and begin to read, understand and ultimately appreciate it. This problem of not being able to find a point of entry may even be more pertinent for non-native speakers or language learners. Language students have different proficiency and reading comprehension levels. They come from diverse socio-cultural backgrounds and bring specific life experiences and expectations to 
classroom readings, so it follows that different students will make sense of what they read differently (Holland, 1990). Within the reader-response framework, multiple readers make the interpretation of the same text fluid, not fixed. Consequently, there are infinite interpretations of each text since each reader brings his/her unique character, personality, and expectations. Thus, reading is a highly personal act during which we, the readers, after having met all the characters ultimately meet ourselves, or as James Joyce pointed out and Holland (1975) adopted it and used it to depict this process so aptly: "We walk through ourselves meeting robbers, ghosts, giants, old men, young men, wives, widows, brothers-in-law. But, always meeting ourselves" (p. 113).

When we read, indeed we may meet all these characters in our mind and within our own life experiences and expectations. This idea rang true for the participants in the present study as they, during the reading and layering processes, at various times reported that there were 'parts of them, their lives' in the stories they were reading.

\section{Method}

\section{Participants}

The participants in the study were two Japanese female college graduates who were taking a high-intermediate language class at an educational institution in the North-East United States. For the purpose of this study, their names were changed to Aniko (twentyseven years old) and Kimiko (thirty-five years old). They both used to work in Japan but were not working in the USA. They were both married without children. They had spent about four years in the United States at the time this project was conducted.

\section{Materials}

The two stories used to generate data and responses were "Happy" by Joyce Carol Oates and "The Story of an Hour" by Kate Chopin. Both stories were written by female writers and involved female characters: in "Happy" the main character is an adolescent girl, and in "The Story of an Hour" it is a married woman. Family and marriage are addressed to varying degrees in both. This aspect reflected the gender theme on the syllabus as well as the overarching concepts of family relationships, dependence and independence. The short story "Happy" is about a daughter who returns from college to spend Christmas vacation with her mother. At the airport, the daughter meets her new stepfather. As they begin the journey home, the girl's emotional and psychological journey unfolds. The three characters in the story are nameless. In the second story "The Story of an Hour" Mrs. Mallard gets the news of her husband's sudden death. She instantly experiences a great sense of liberation and joy only to find out that the news was due to a misunderstanding. Her husband appears at the doorstep and she herself dies of "joy that kills."

\section{Data collection and procedure}

Since this study is ethnographic in nature, the data was both generated and collected by assigning reader response tasks to students. The specific method for generating data is called layering: students were asked to do multiple readings of each short story and record their responses each time. The data collection instrument was a 'Reader-Response 
Worksheet' here also called the reading log because the students compiled a number of such worksheets thus creating a $\log$ (see Appendix A for the generic form of the sheet $/ \log$ ). The worksheet contained two columns with instructions to students:

\section{Words/Phrases: \\ "Record the words that you feel are important to you; or that you feel you want to react to”.}

\section{Why I chose The Words:}

"Write down why you chose a particular word or a phrase; explain how it made you feel; or what you connected the word with (what kind of experiences did you connect that word to, from your own life)".

The same steps of layering were repeated for both stories: the students would read the story in class or at home, do some initial responding and then share (in groups or pairs) general reactions such as liking or disliking the story. Then they would be given the worksheets to use at home while reading for the second time. They would return to class and discuss the story's themes and relevant cultural concepts. They would go home and read the story again and respond to it. The final stage asked the participants to reread their responses and comment on them. The teacher regularly read the logs and returned them to the students without making any comments in the logs themselves. However, she would address, indirectly, the DEFT components by probing for expectations or fantasies while observing pair work. This method is in line with an 'unobtrusive' observational model of applying reader-response in the classroom, also known as 'undirected' (e.g., Dias, 1995).

\section{The study}

In order to show the process of reading and to trace the responses in relationship to DEFT, each story will be presented in the following way: first the layering process will be described from the first to the fourth reading. Then, the data generated during layering will be analyzed. Since the elements of the DEFT were not all noticeable right away but rather they emerged throughout the process, the chronology of the reading and responding is important - it shows the reading transaction processes. Thus, this article is organized following chronological rather than thematic order.

\section{Layering Processes for the First Story "Happy"}

The students were given a handout called "Reader Response: A Guide for Students"(Appendix D) and asked to read the story for the first time in class. Some vocabulary work was done in class. The teacher asked general questions, such as "Did you like the story"? and "Why or why not?" or "How did you feel about the girl?" The participants' answers were also general, and somewhat unenthusiastic. The students thought the story was 'okay' and 'interesting'. Although the students were encouraged to freely express their reactions in a relaxed, friendly manner, they remained quiet in the classroom, a phenomenon documented in research (e.g., Kramsch, 1996). They limited their utterances to short responses such as, "She was sad" or "The girl was uncomfortable" but did not venture further. The responses appeared to indicate struggle, either because the students felt unable, or ill equipped, to go beyond flat statements in the 
public space of the classroom. It could also be that these two participants did not feel an initial connection to the story. They showed no apparent liking of the story.

The perceived student reluctance (or inability) to comment and their apparent disliking of the story provided an opportunity to indirectly introduce the DEFT model as a tool for dealing with 'fears' of the 'unknown' that the theme of the story might have stirred up in the students. The teacher gave a handout to students with questions that refer to fear, expectations and fantasies (see Appendix E). The students read the story at home for the second time and recorded their responses to self-selected words. In order to initiate the discussion about fears, the teacher asked the students to read some of the words from the story that they recorded in the logs. The following expressions came up: "the pancake makeup, in a husky voice, his sideburns grew razor sharp". The teacher explained the words in relationship to the story's characters and their realities - those of the newly remarried mother and her new husband. After the vocabulary explanations, the students interacted more but their resistance was still noticeable. They were not engaged with the story on a personal level. Within the DEFT, this behaviour may indicate defenses, or an ego not accepting what it does not understand or cannot tolerate. Perhaps, the 'sordidness' of the main characters created discomfort and disliking in these two Japanese female students.

The third reading and layering generated more comments and perhaps the defenses began to come down. This stage of class work called for the sharing of log entries in pairs. The students didn't have to talk to the teacher, but they did speak with their conversation partners. This approach appeared helpful because the students discovered that others experienced similar disliking of some aspects of the story (e.g., the sordidness of the new husband). Such realizations, facilitated by sheltered participation (i.e., pair and group work), are particularly valuable because class work is at a level of sharing not judging or criticizing one's ability to respond to the story. The teacher walked around, took random notes but did not make comments or interfered in any way with the discussion.

The final layering of "Happy" brought more sharing when discussing the mother's second marriage and the daughter-stepfather relationship. The process clearly helped by gradually increasing the levels of personal engagement and also finding a point of entry, initially absent on the part of both students.

\section{Discussion of Layering Results for the First Story "Happy"}

The layering process revealed a few insights into the elements of the DEFT. Of the two participants, Kimiko appeared more willing to explore the multiple meanings of the story "Happy". She was older and also more comfortable discussing her feelings and talking about her childhood, thus showing an ability to transform her fears into the beginnings of an understanding of how the story related to her own life. The second student, Aniko, however, participated less in the discussions admitting that she disliked the story and was unable to identify with either the plot or the characters. She saw the story as 'silly' because the characters were doing 'silly' things (e.g., the mother drinking in front of her daughter). Any indirect attempt by the teacher to elicit responses to the story by trying to get Aniko to engage in discussing her own relationship with her mother met with strong resistance. Aniko maintained that her childhood was happy and her parents were such different people that she simply could not imagine a family like the one depicted in the story. 
Within the DEFT model, Aniko's reactions can be interpreted as an expression of discomfort discussing what could be perceived, socially, or otherwise, as inappropriate behavior. Breaking social norms, such as a middle-aged woman (and a mother) having a sexually charged relationship with her new younger husband may have contributed to Aniko's defensive reactions. Kimiko also hinted that such a relationship was 'wrong,' particularly because it took the mother away from what should have been her first priority - her daughter. She wrote (Appendix B-1):

"It's inappropriate action that mother drink, with her lover at the bar and that show adults' world to their children".

Interestingly, both Aniko and Kimiko commented on the hugs and body contact between the mother and the daughter. It was more than they had ever experienced growing up, they said. This particular point in the story incited a discussion about "body distance" in two cultures. They revered the closeness Americans exhibit when with their children or family members. Kimiko's log entries included comments on the word 'hug' by stating that the scene where the mother and the daughter hug was 'impressive' because of "the difference of body language between Westerners and [the] Japanese" (see Appendix B1). The desire to experience closer family relationships may have contributed to this reaction. When viewed through DEFT, the layering process seems to have brought out some elements of fantasy in their responses.

\section{Layering Processes for the Second Story "The Story of an Hour"}

The layering steps for the first short story appeared to have helped the process of reading and responding to the second one. The students knew what to expect from the layering. In "The Story of an Hour," the main protagonist, Mrs. Mallard, is mistakenly informed of the presumed death of her husband. She experiences a flood of liberating feelings and overwhelming joy. But, when her husband shows up at the door alive and well, she unexpectedly dies.

This time, the process of layering was slightly altered so the students had to do the first reading at home and record self-selected words and phrases in their logs. In class, the first discussion turned out to be lively: the students had a lot to say about this story. There were a lot of language points though that needed attention, so class time was spent on explaining the meaning of expressions such as "in broken sentences", "hastened to forestall", "away off yonder", "her fancy was running riot", and "save with love". These phrases were either new vocabulary or confusing usage in the text. English language learners tend to feel more secure when they understand the vocabulary that they perceive as difficult, so time was spent on vocabulary explanations.

After the second round of reading and recording the reactions in their logs (at home), the second-class session focused on discussing the responses in pairs. The same steps were repeated for the third reading. After the forth reading, a general discussion of gender themes ensued. The teacher took notes of the discussion, but did not add her reactions to it. 


\section{Discussion of Layering Results for the Second Story}

The participants Aniko and Kimiko had different reactions to the story. Their entries revealed a fair number of personal notes. Aniko did not like Mrs. Mallard's reaction to her husband's death. Mrs. Mallard's marriage was, in Aniko's view, "bad and unsuccessful" (see Appendix C-3). Aniko's defenses seemed high probably preventing her from engaging with the text more fully. The progression towards finding a point of entry was slow for Aniko. Contrary to Aniko, Kimiko found the story interesting (see Appendix B-2). She thought about "movement of emotion, how it came out...interesting expressions". She was moved by the words "subtle, elusive...words that could explain everything". Kimiko understood Mrs. Mallard's emotions, she said, but she could not understand "what her [Kimiko's] real emotion [was]". She was confused. Slowly she connected her marital experience to that of Mrs. Mallard's. That was a liberating transformation for Kimiko.

\section{Kimiko's Layering}

The first round of Kimiko's responses dealt with the feeling of joy, of being overwhelmed with, and at the same time motionless from, the "sudden powers of freedom". She wrote (see Appendix B-2):

Even though her [Mrs. Mallard's] conscience was beyond common (generally accepted) sense, her character attracts me very much. I understand such kind of feeling [physical exhaustion that haunted her body] like condition of despair. It reminds [me] of similar experience and condition.

Kimiko found a connection with the character and an entry into the story. She appeared engrossed in the story and her involvement suggested, within Holland's framework (1975), an "absorbed type" of a reader. During the second reading, Kimoko recorded a list of adjectives, such as "subtle, elusive, fearful, and tumultuous". Kimiko also chose to quote "repression, pulses, and blood". She followed the process of awakening possibly because she found it relevant to her life. She further wrote (Appendix B-3):

"The most important thing is our feeling (not logical thinking) or repressed feeling".

Within the DEFT model, this could be interpreted as an expression of one's own fantasy of being emotionally liberated, expressing her feelings freely, not just with her husband or friends, but within her own culture. She also recorded her own search for something that she could not name (Appendix B-3):

"I feel that I am expecting and looking for something (but I don't know) into this story".

Kimiko might have expected to find answers to her own sense of repression, or a feeling of being torn between traditional Japanese spousal duty and personal ambition. Her own choices of words are - on some level - almost as strong as Chopin's (Appendix B-3): 
"[I] was really excited by these vivid expression!" [Here relating to "her pulses beat

fast and the...blood warmed and relaxed every inch of her body.]

Kimiko also traced the emergence of the 'new' Mrs. Mallard evidenced in the list she made: "self-assertion, body and soul free, days that would be her own". Within the DEFT framework, her comments on the "feverish triumph" may have revealed fear, perhaps of her own exaltation or hidden desires to be free (Appendix B-4):

"I'm afraid of complete things (referring to 'triumph'), perfect and unshakeable victory. In this situation, I always think about unexpected twisted ending”.

While working through her responses, Kimiko made sense of things based on her own life experience. Drawing such personal parallels clearly helped her with story interpretation and comprehension. With each round of reading, Kimiko made new discoveries and produced fuller responses. Particularly revealing is Kimiko's third round of responses. She repeated some of the previously recorded phrases form the story, such as "haunted her body, tumultuously, and pulses", and she made personal connections to them (Appendix B-5):

"This story reminds me of my own painful experience. In spite of these feelings, I can't stop reading these stories. Maybe like Louise [Mrs. Mallard], my soul look for (wait for) something. But I'm not looking for my husband's death".

At one point, Kimiko resorted to Japanese and wrote in Japanese characters on the page for lack of the right word that would most closely define her feelings (Appendix B-5). Although she might have not had all the English she wanted in order to express her reactions, it seems that the lack of full language proficiency was not an obstacle in the layering process. The students utilized whatever English they had in order to work through the reading. The life of the story's characters and the literary world took over language concerns. Each layer of responding seems to have taken Kimiko deeper into the text and closer to her own feelings and personal realizations.

\section{Aniko's Layering}

It was apparent that Aniko went through different experiences while reading the story and her recordings showed different reactions. Aniko stated that she came to the text of "The Story of an Hour" with certain expectations. In her words, she was a married woman and therefore wanted to read the story from that point of view. She began responding by writing the following (Aniko's original language is maintained):

"Mrs. Mallard is a married woman as well as me, so I thought (expected) that I would read this story from this point of view and I thought (expected) that I would somewhat identified with her. While going on reading, I felt bad because she was happy (I'm not sure if this word is appropriate or not) to be free although it was happened by her 
husband death [...]I thought that the reason why she was happy is that her marriage had been unsuccessful. I defended myself? I would not be glad to be free in case of my husband's death because our marriage is successful".

Aniko implicitly disliked the idea that Mrs. Mallard's happiness stemmed from her husband's death. She labeled Mrs. Mallard's marriage as being unsuccessful and quickly compared it to her own - which was successful (see Appendix C-3 for the progression of entries and for additional comments and textual clues). It is interesting that Aniko realized that she might have been defending herself. She was trying to rationalize her responses. Within the DEFT framework, Aniko may have rejected the feelings that Mrs. Mallard expressed possibly because Aniko's ego could not tolerate the idea of being happy rather than crushed by one's husband's death. The rejection in this context could be a defense mechanism against her own vague thoughts that she, like many women, felt oppressed (to an extent) in her marriage. However, unlike Kimiko, Aniko did not choose to pursue this avenue of exploration, although she could have. The defense against possible self-realizations and discoveries about her condition may have been the strongest element in her reading process. The second reading produced a very short response. Aniko continued to explain her reading process (Appendix C-4):

"When I read the story for the second time I tried to find the difference between her and me. That's one reason I read the story considering the era and environment. Of course whenever I read any story background is very important".

Aniko's rational approach to the reading was evidenced in her statements that "background is very important" (i.e., the information about the author provided in class). She then further explained (Appendix C-4):

"She [Mrs. Mallard] was suppressed a lot as a woman in such kind of time. I'm not suppressed at all by anything".

An interesting feature of Aniko's log entry is her heightened sense of self. She worked through the text by making comparisons between what she thought was driving Mrs. Mallard's actions and her own actions. During the third reading, Aniko commented again on her reading approach (Appendix C-4):

\section{"I read carefully about her emotional progress".}

The first sentence in her log written for the third round of reading appears to qualify her approach to responding method again. Under a subheading "Storm of Grief" Aniko listed the words from the text: "paralyzed, physical exhaustion, suspension of intelligent taught” (Appendix C-4) as examples of Mrs. Mallard's grief, but perhaps also as her own paralysis and suspension. Then, she traced the transition from grief - "striving to beat back, relaxed, exalted" - to joy. In her explanation (given in a boxed-off paragraph), Aniko tried to come up with alternative reasons for Mrs. Mallard's still unacceptable happy feelings (Appendix C-5): 
"I still try to think the possibility that she made herself think that in order to protect herself, weaken the sorrow".

In her later re-reading of the entries, Aniko called this process an elixir. After three readings of the story, Aniko was still stubbornly trying to come up with excuses for the way Mrs. Mallard was feeling. Within Holland's character theme, obstinacy would be the dominant trait. Aniko couldn't let go of the feelings created by the initial contact with the story and her responses to it: the initial strong rejection of the overarching premise of a wife feeling joyous upon hearing the news of her husband's death.

During the fourth reading, Aniko focused on Mrs. Mallard's and her husband's feelings for each other. She wrote that for the first time during this final reading, she noticed that Mr. Mallard loved his wife (Appendix C-5). Aniko showed partial understanding of Mrs. Mallard's feelings, and though still rejecting them, she slightly sympathized with her (Appendix C-5):

"Still, I don't want to accept that. But can imagine her feeling (not completely). I was afraid that I might start thinking if I'm inhibited and suppressed or not".

On the final page of the log she unexpectedly opened up and admitted (Appendix C-6) her fears:

"I have avoided to read these kind of story about marriage life because whenever I read these kind of story, I become nervous".

It is this truth that perhaps freed Aniko's responses. She realized that most of the time, she was avoiding such topics instead of dealing with them. The multi-reading model appears to have assisted the process of finding a point of entry. Though it took four readings in order to reach that level, it is certainly an important point for teaching as it illustrates the process that can help the students to achieve fuller reading experiences. Clearly, not all classes can set aside this amount of time to work on facilitating the process of finding a point of entry into the text, but this analysis shows a useful way of encouraging the journey towards self-realizations.

\section{Additional findings}

In order to gauge the results of the complex process of layering that the two participants completed for both short stories, additional elements were considered such as: scope of responses, amount of detail, any noticeable change in attitude towards the characters, levels of personal associations, and spatial/topographical aspects such as special notes on the page, the use of boxes for words or sentences, underlining, capitalization of certain words and any additional comments done during the last stage of layering. The discussion below takes all of these elements together based on the DEFT model.

Kimiko's answers grew in scope and depth from the first responses to "Happy" to the final entry to the second story and they more closely followed the worksheet format. In layering to "The Story of an Hour", she grappled with social and moral aspects of the 
story in relation to her own life. Aniko, however, had a very different approach to log writing and responding. The first thing that stands out in her entries is the organizational style of the responses. Her first response was really a neat vocabulary list. She began by reflecting on the progression of her understanding of the story and the language used (Appendix C-3). From the start, Aniko tended to be more practical and rational in her approach. She took time to check each new word and to labor over the meaning of some syntactically entangled sentences. Her self-awareness as a language learner was also high as she wrote (Appendix C-3):

"Moreover as a second language learner, I tend to emphasize understanding the meaning of word and sentence rather than the theme".

Aniko started her responses with pragmatism, possibly because she struggled to find a point of entry. Her defense was to use what she knew: the method of listing vocabulary, writing the words down, checking them for meaning and systematically working through each paragraph, as if doing a language exercise for homework.

In terms of the volume of responses, the second story yielded more copious log entries. Kimiko filled three pages with the phrases from the original text (see Appendix B-2 to B5), in comparison to only one page she filled in response to "Happy" (Appendix B-1). The making of meaning seems to have been created through Kimiko's associations to her own life experiences and, in that, it lends support to Holland's suppositions about the point of entry. She connected her own feelings with the ones Mrs. Mallard experienced. Kimiko's defenses could have been down, as she seemed to be no stranger to the feelings of despair or unconscious searching for fulfillment. Kimiko said that she had such times when "[she] didn't feel anything, couldn't think and didn't know why [she] was crying" (see Appendix B-1).

When considering Aniko's responses within the DEFT model, it appears that she revealed her fears as an afterthought, or in addition to her primary response of rejecting, disagreeing or disliking. Her defenses seemed to have slightly come down in the last layering process in the form of a postscript (P.S.), disclosing her suspicion about women's position in the society "because of [her] experience" (Appendix C-6). Although she used the afterthought format of the post scriptum, she spoke more openly in it about her true reactions to Mrs. Mallard's social conditioning. In some ways, the P.S. was a hiding place that allowed these comments to appear as being less important, or to be overlooked. But in fact, they may have been important feelings. Aniko added the P.S. during her final review of her entries.

Finally, the log entries could be read as a long narrative because each student reader, in a way, 'storied' her own story by "creating her experience of the literary work from her own lifestyle" (Holland, 1975, p. 63). Aniko stubbornly defended her beliefs about marriage but she reached at least a level of sympathizing with the character, though not accepting what she disliked. Kimiko enjoyed the experience and shared her own life stories. Within the two-month process, both students seemed to have grown more comfortable with their responses. Their explorations went beyond the surface to reflect personal and general life experiences. 


\section{Conclusion}

The appeal of the DEFT model lies in its considerable potential to be a self-sufficient reading tool. The study in this article has shown that the texts were engaged at a very personal level, perhaps because it may be a natural point of entry for most people - to tap into what they already have: their own life experience and move from there to more abstract ideas. Critics could argue that this very aspect of the reader-response approach may bring diametrically opposite outcomes. Some students may feel intimidated by being asked to share those very private feelings - albeit in their logs only, and therefore their defenses may be an impediment to successful reading experiences. However, the use of the DEFT model allows for gradual adaptation. The teacher and the students can work through the reading stages at different points in time and the re-readings can help build students' confidence and ease.

Although this is a case study detailing the reading experiences of only two student readers, some conclusions could be made - though cautiously, pending larger studies and replications of this one. The students seem to have made a number of gains from their participation. By employing the reader-response model, the students, as evidenced in their logs, arrived at new insights about themselves, the social context around them, and the story itself. As a result, they may be able to use their experience with this approach to other literary texts in the future and grow intellectually, emotionally and socially (Vinz, 1999). These generally positive reading experiences could influence the amount and quality of future engagements with literature.

Finally, the log entries might have helped their language and vocabulary development. Despite some textual challenges, difficult vocabulary and expressions less frequently heard in daily English, these second-language learners showed that they could read and work with short stories as native speakers can. The model can be used for both populations-- native and non-native speakers of English. Future classroom methodologies can be adapted to more closely meet the needs of language learners, such as building into the layering process more initial work on language and vocabulary. Although not the focus of this particular study, it is recommended that future studies consider the relationship between the DEFT model and SLA.

\section{Acknowledgments}

I wish to thank Professor Ruth Vinz of Columbia University (Teachers College) for introducing Reader Response Criticism and Holland's work to me. She opened new avenues of literary exploration in my classrooms and changed my view of reading, text and the role of the reader. Special thanks go to my students for their participation in this study. 


\section{References}

Carter, R. \& Burton, D. (1982). Literary text and language study. London, UK: Edward Arnold.

Carter, R. \& Long, M. (1991). Teaching literature. Harlow, UK: Longman.

Chopin, K. "The Story of an Hour". http://www.KateChopin.org/the-story-of-an-hour

Collie, J. \& Slater, S. (2002). Literature in the language classroom. Cambridge: UK: CUP.

Dias, P. (1995). Reading and responding to poetry: Patterns in the process. Portsmouth, NH: Boyton/Cook.

Ellis, R. (1985). Understanding second language acquisition. Oxford, UK: OUP.

Grabe, W. (2004). Research on teaching reading. Annual Review of Applied Linguistics, 24, 44-69.

Hill, J. (1986). Using literature in language teaching. London, UK: Macmillan.

Holland, N. N. (1968). The dynamics of literary response. New York: OUP.

Holland, N. N. (1975). 5 readers reading. New Haven: Yale University Press.

Holland, N. N. (1980). Unity. Identity. Text. Self. In J. Tompkins (Ed.), Readerresponse criticism (pp. 118-134). Baltimore: Johns Hopkins UP.

Holland, N. N. (1985). Reading readers reading. In C. R. Cooper (Ed.), Researching response to literature and the teaching of literature: Points of departure (pp. 3-12). Norwood, NJ: Ablex Publishing Corporation.

Holland, N. N. (1986). Re-covering 'The Purloined Letter': Reading as a personal transaction. In R. C. Davis (Ed.), Contemporary literary criticism (pp. 363-376). NY: Longman.

Holland, N. N. (1990). Holland's guide to psychoanalytic psychology and literature-andpsychology. New York, NY:OUP.

Holland, N. N. (1993). A portrait as rebellion. In R.B. Kreshner (Ed.), A portrait of an artist as a young man: Case studies in literary criticism (pp. 279-294). New York, NY: Bedford Books.

Kramsch, C. (1996). Literary texts in the classroom: A discourse. In L. A. Jacobus (Ed.), Teaching literature (pp. 121-136). Englewood Cliffs, NJ: Prentice Hall.

Lazar, G. (2000). Literature and language teaching. Cambridge, UK: CUP.

Meisel, P. (1981). Freud: A collection of critical essays. Englewood Cliffs, NJ: Prentice Hall.

Oates, J. C. (1986). “Happy.” In Raven's wing. New York, NY: E. P. Dutton.

Povey, J. F. (1967). Literature in TESOL programs: The Language and the culture. TESOL Quarterly, 1(2), 40-46.

Redmann, J. (2005). An interactive reading journal for all levels of foreign language curricula. Foreign Language Annals, 38(4), 484-493.

Rosenblatt, L. (1968). Literature as exploration. New York, NY: Noble.

Sadoski, M., et al. (1988). Imagination in story response: Relationships between imagery, affect, and structural importance. Reading Research Quarterly, 23(3), 320-336.

Spack, R. (1985). Literature, reading, writing and ESL: Bridging the gaps. TESOL Quarterly, 19(4), 703-725.

Topping, D.M. (1968). Linguistics or literature: An approach to language. TESOL Quarterly, 2(2), 95-100.

Vinz, R. (1999). "Horrorscapes". In Forming adolescent identity and desire. Manuscript.

Widdowson, H.G. (1983). Talking shop: On literature and ELT. English Language Teaching Journal, 37(1), 30-35.

Wright, E. (1984). Psychoanalytic criticism: Theory and practice. New York, NY: Methuen.

Language and Psychoanalysis, 2013, 2 (1), 20-49

http://dx.doi.org/10.7565/landp.2013.0002 


\section{Appendix A}

Appendix A: Worksheet (Log)

READER-RESPONSE WORKSHEET

\section{WORDS/PHRASES}

Record the words that you feel are important to you; or that you feel you react to

\section{WHY I CHOSE THEM}

Tell me why you chose a particular word; Explain how it made you feel; or what you connected it with (the kind of experiences from your life) 


\section{Appendix B-1}

Appendix B-1

HAPPY

Title: tiny, small happiness in the difficult situation.

before readig) soft light in the darkress

$$
\text { (kind of ) }
$$

QS. The girl might part from her mothen with, bad feeling.

- Even if time har passed to melt this folig, she. still has complex foling and she cant accept her.

- hug: impressire sceme forme. (difference of body language betureen wetrues and Ispon

- The girl theeps $\wedge$ distance from har mother.

- the feels her motherisgetting old. At the same time she recogrizes Les mother as a woman.

Q Mothers nero husband ... light person.

Mother: the looks happy. without reason.

(3) The girl: the suppressesher fealif _ but not indifferent

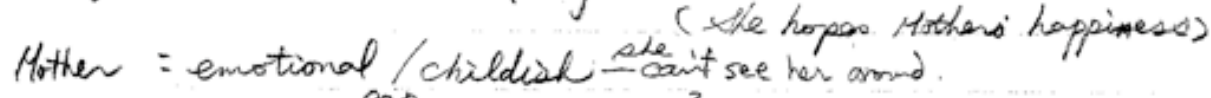
(10). The gir/recognizes distance betwren children and adulto listenigg to

( It's inapprophiate cetion that mothen drink with her loven at the bar and that show adults wold to their children., )

(5). Git'snotieris unilateral (the rever try to find her dangitersivivice)

- Mothers's new huoband "Yous morter is a high class lady."

$$
\text { "Theres nobody in the wolld precions to me as that lady." }
$$

$\rightarrow$ Author tells us that everything (including "happines") is relatire would. ( $\leftrightarrow$ absolure)

Happiness is different depands on people. in the 


\section{Appendix B-2}

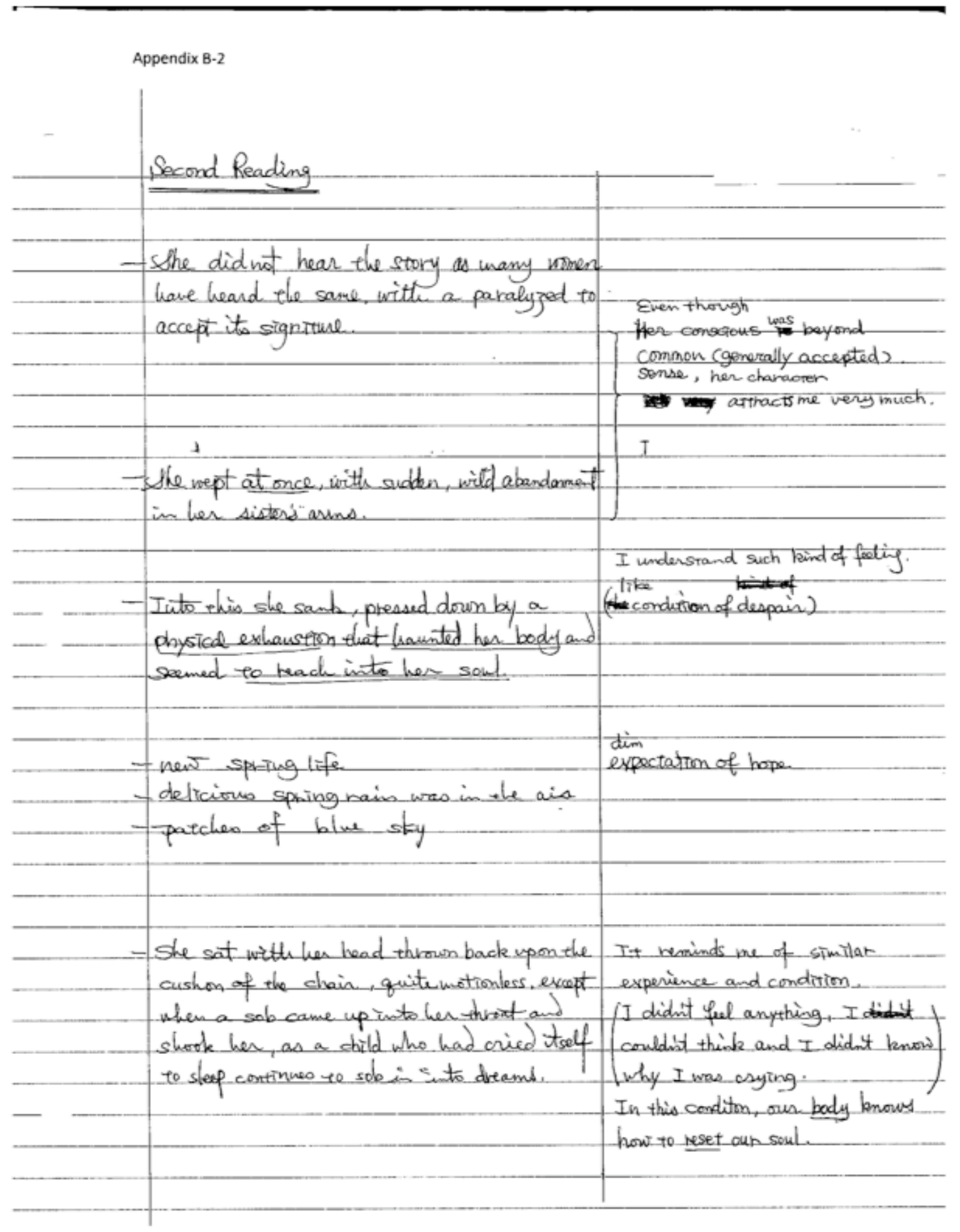




\section{Appendix B-3}

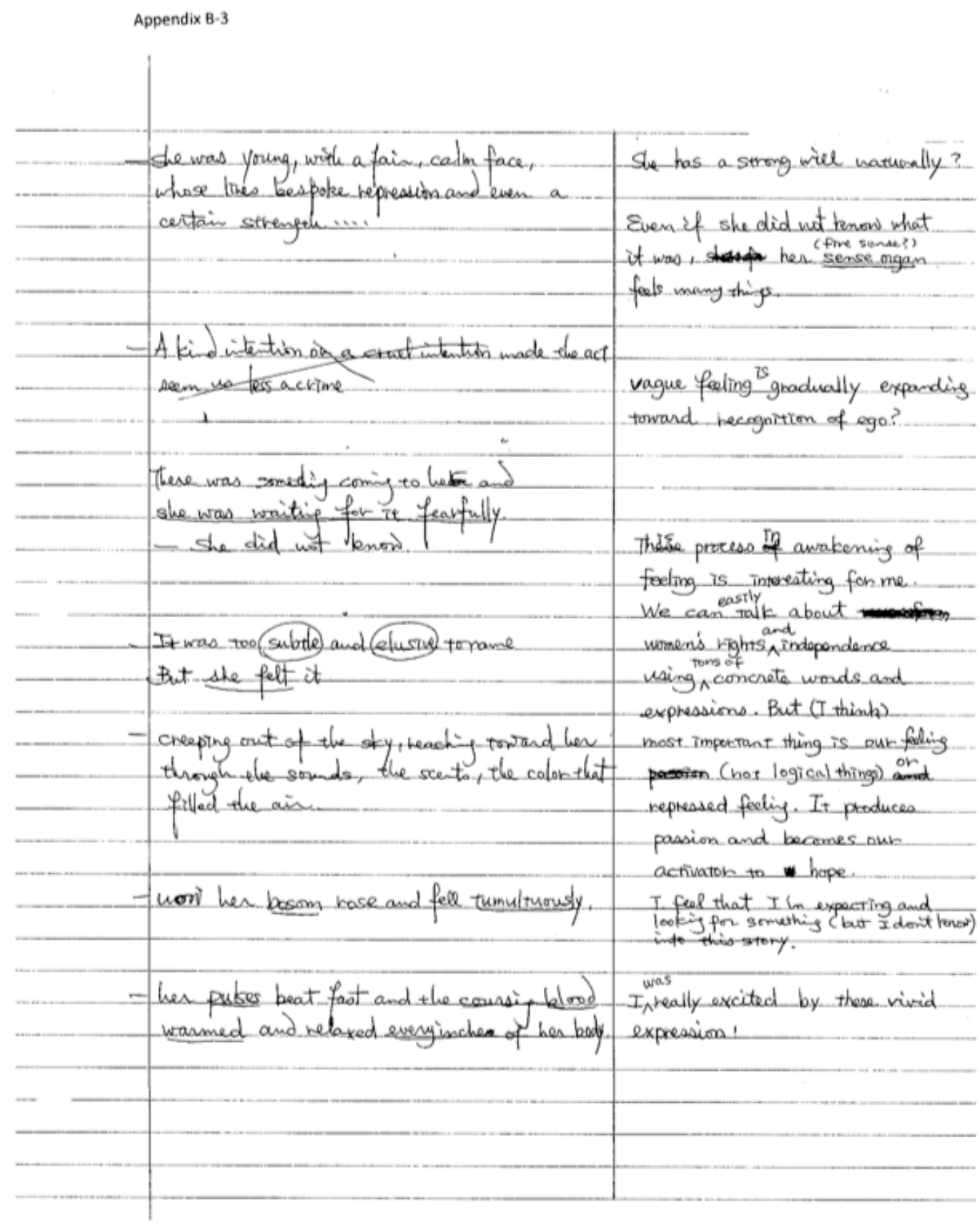




\section{Appendix B-4}

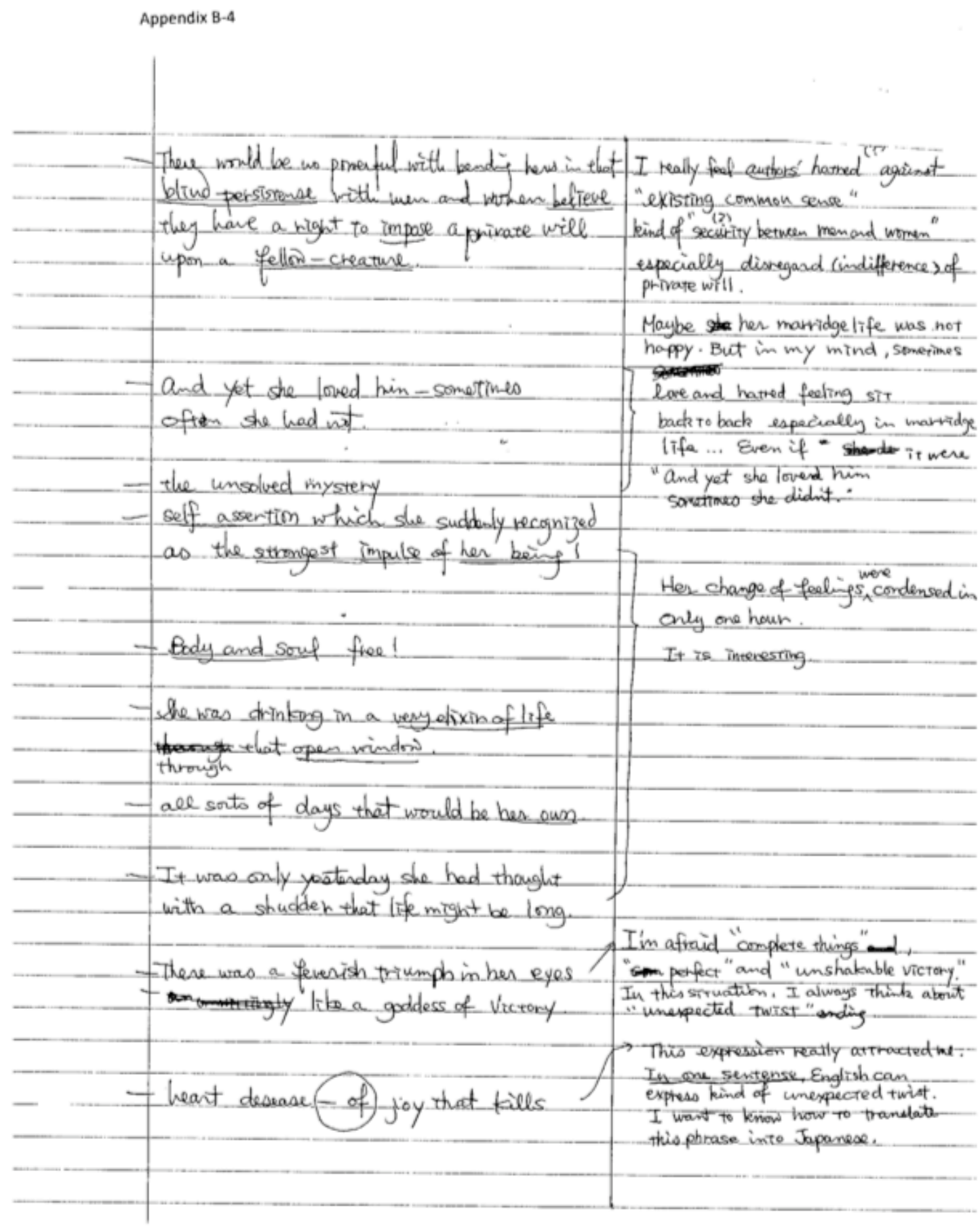




\section{Appendix B-5}

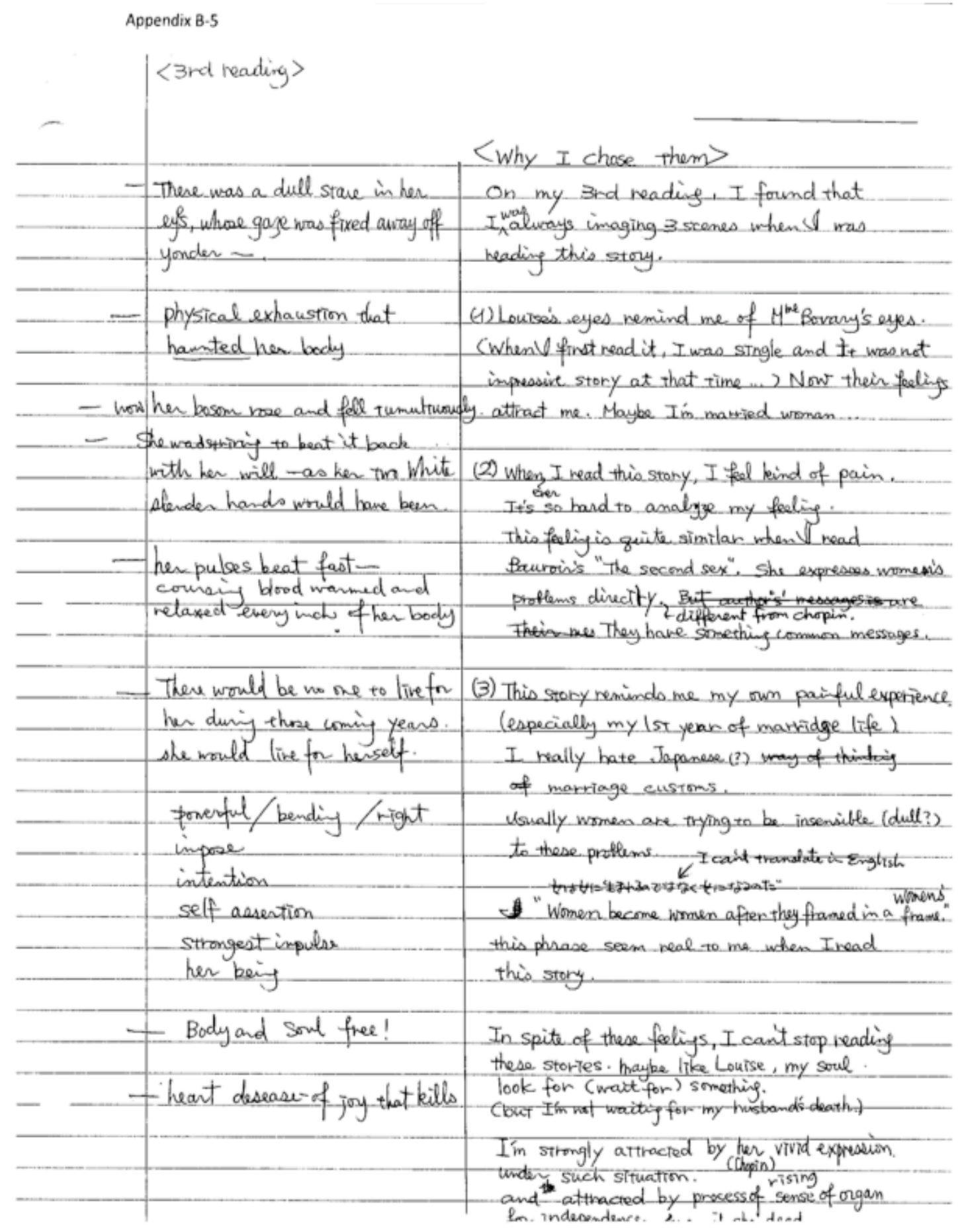




\section{Appendix C-1}

Appendix C-1

- starm of grief

After the storm, it's always clear day.

- Open window

She opened hev mind?

- a comoritable roomy chair

She is fuce from suppression

- hew spring life

her new life withour husband.

- suspension of intelligant thought She had been restrained bx intelligent thought, sowhen she lost it, then heal mind came out (intellyant theosed is commonsense of sociery

- She was waiting for it, fearfully... She was afrast of accepting the idea

- coursing blood warmed and $\rightarrow$ her heart thouble was owing to helaxed every inch of her boly. her suppression?

She seemed to get better from the heart proberem 


\section{Appendix C-2}

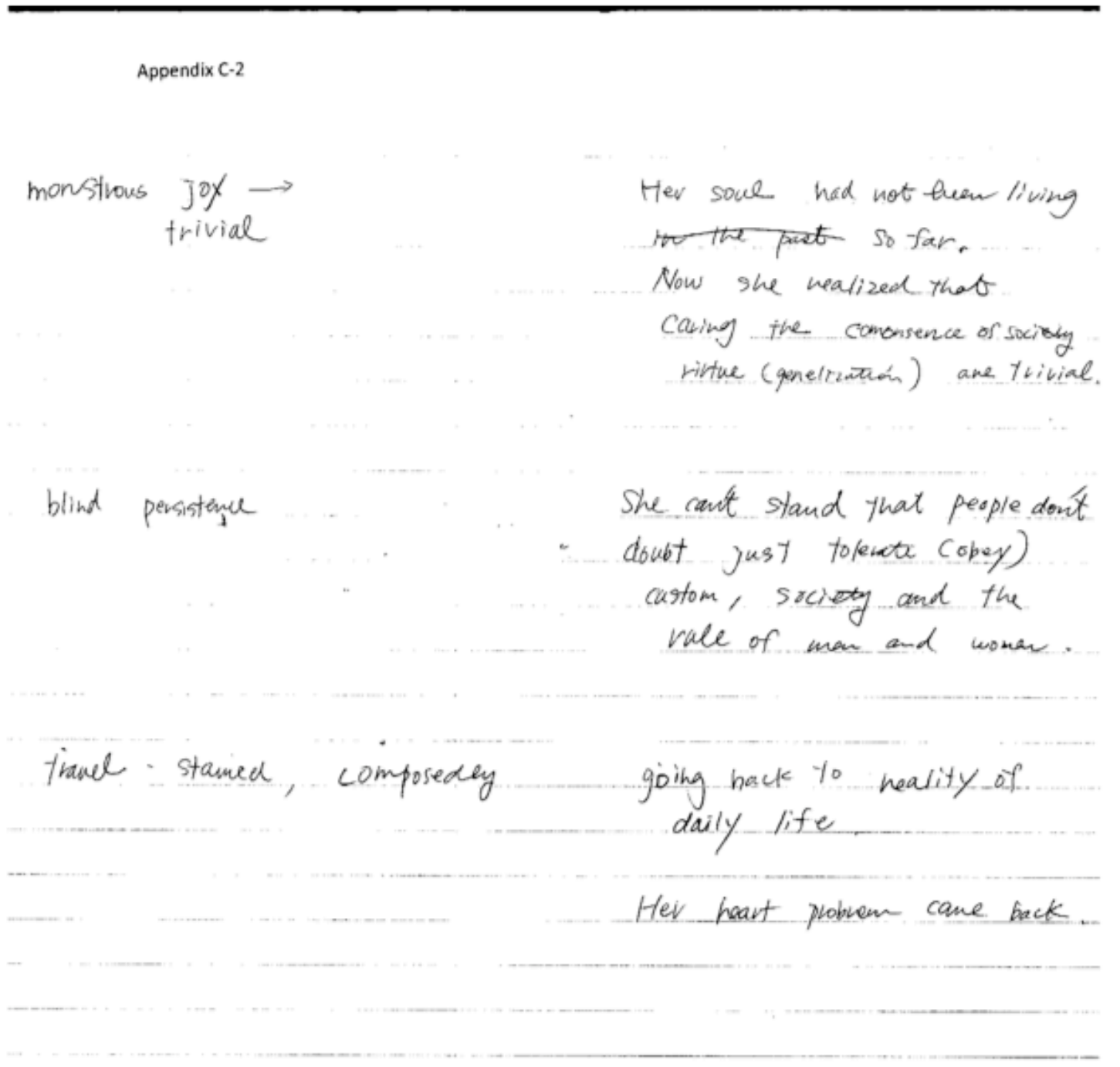




\section{Appendix C-3}

Appendix C-3

Four elements

The developement (- progress) of my understanding is nery slow because I took twee times neading to understond the meaning of sentences and nods. Moreover, as a second language reader I tend to emphasize understanding the meaning of ward and sentence rather than the theme.

$\star$ the Fint time

- Mrs Mallard is a married nomam as well as me, so $I$ thousat that I would read this story from this point of view and I thougat that I would semowat identifind with her

H

- While going an reading, I feet bad berause she was haspy (I'm not sune if this wand is appropriate or not) to be free althoager itwaphened by an hasband deatch $\sqrt{5}$

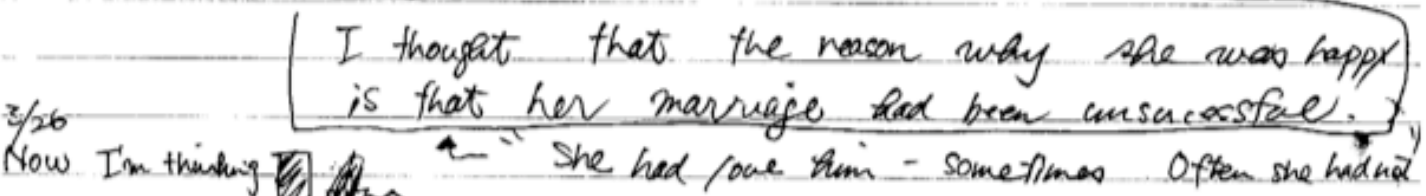
I feet like that 3

$I$ defended mpeef

I would not be glad to be free in case of my husband s deatho because 


\section{Appendix C-4}

Appendix C-4

* For the 2nd time

I guess

I tried to find the diffenence between her and me.

That's one nasow. I read the story considening

the ara und envirament. Of course

whenever I read any story backgrand is

- very important.

She was supprossed a lot as a woman in such kind of time

凹

Ith not suppressed at all by angthing

(1) mprees )

$\$$ For the 3id time

I nead canefully about the hew emotional progness

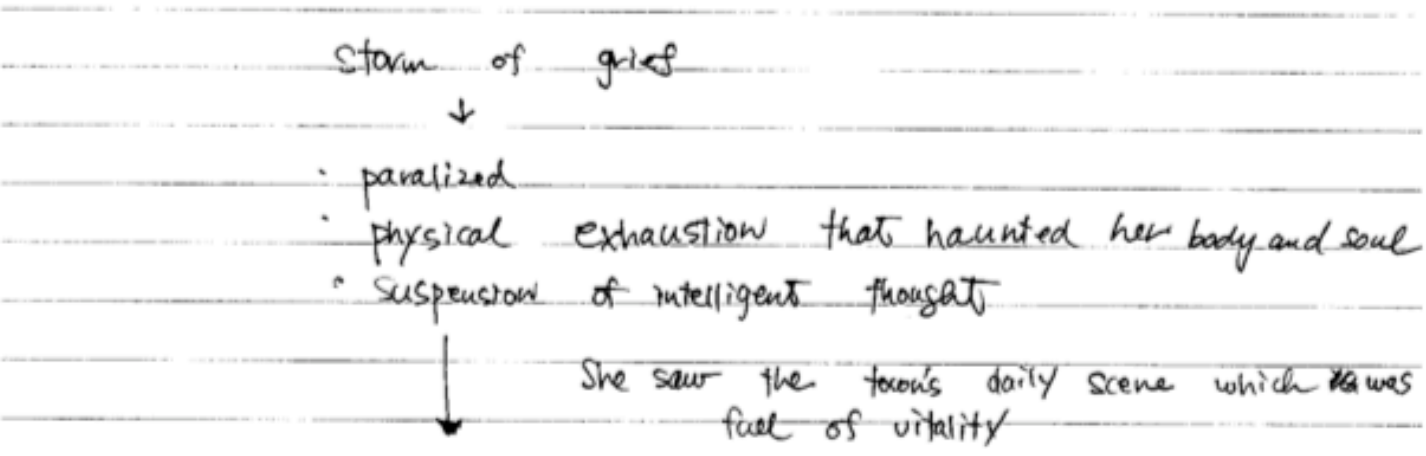

Language and Psychoanalysis, 2013, 2 (1), 20-49

http://dx.doi.org/10.7565/landp.2013.0002 


\section{Appendix C-5}

Appendix C-5

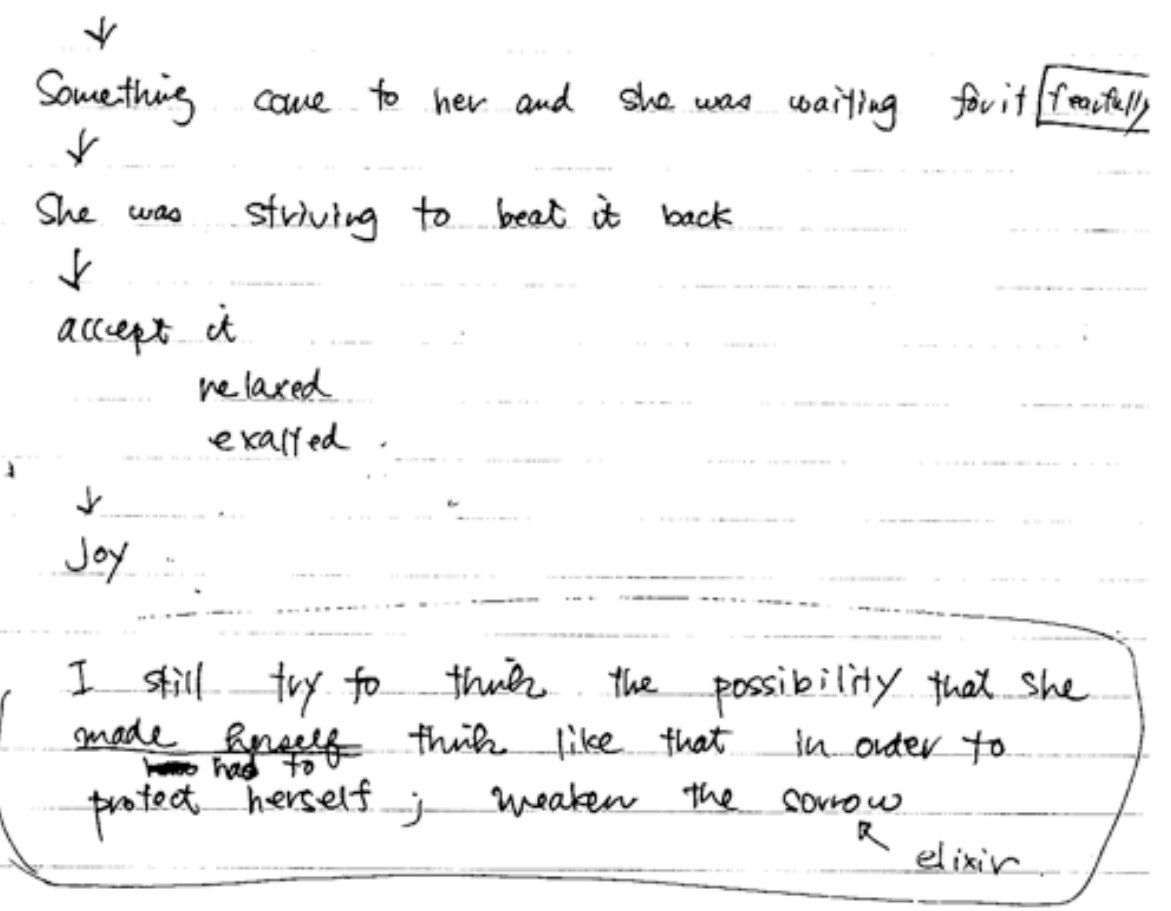

\$ For the tra fine

At the first meeting, I learned that

her husband had loved her.

$L_{D}$ Now, I have to comect my subjective impuassion.

Ifear $\begin{aligned} & \text { Still, I dont want to accept that but } \\ & \text { I can imagine her feeling (not completery) } \\ & \text { I was afraid that I mugat start thinkenig } \\ & \text { if IIm inhibited and suppressed or not. }\end{aligned}$ 


\section{Appendix C-6}

Appendix C-6

Actually, I have avoided to read these kind of stony, abot mainge life because whonever I read these kind of story, I become nervous.

I had left this probrem unsolued and I mill do so again

ps I feel like that the proghess she accepied her idea is sommenhat of similer to mine. I'm suspicious that .

Not orly how hashand (society)

but alco hereeg inhihited ner

$\longrightarrow$ because of my experience.

$\uparrow$

She had tried to conform to the society

she had foced heseif

Taking advantage of her hasbandis death she accepled herself. 


\section{Appendix D}

Appendix D

\section{Reader Response: A Guide for Students}

Story Title:

Story Author:

\section{Recording Words and Phrases}

In this column, note down the words that draw your attention, that you find different, powerful, strange, beautiful, horrible, personal, relevant to your life.

How to find such words?

As you are reading the story, record the words that draw your attention because they are new to you, or they are long, or they are strong-sounding such as 'razorsharp"- you know that a razor is a sharp instrument so having such a word in the text may have a special meaning.

How to Express Your Feelings?

You can try to connect to your feelings by asking: How do I feel about this character? Do I care? Do I feel sad about their life? Do I dislike them? If so why? Do I feel anger, ambivalence? These questions should help you express your reactions to the story. List some of your feelings here, as you are reading the story for the first time in
class.

What do you think are the main themes in this story?

What do you think, personally, about the theme: how is it relevant to you? How does it relate to YOU, YOUR life?

\section{HELP WITH THE READING LOG TASK} As you are reading the short story at home, for each paragraph record in your log
the following:

- The most important happening or action

- The most interesting characters or thoughts

- What images you developed as you were reading 


\section{Appendix E}

Appendix E

Second Round of Reading and Layering: A Guide for Students

Here are some helpful tips you should consider while reading the short story for the second time in earnest at home. Remember that we touched on most of the elements of the reader-response in class.

1. Write down what you think the title means. Did it affect your expectations of the content of the story? As we said in class, when we start to read a story, we usually have some sense of what we may expect, or what we think would happen in the story. Sometimes, the expectations are very pronounced if we heard recommendations from friends, or we read the review of the story. But most of the time, we don't know much about the story. Still, with the first paragraph, we start building expectations. As we read on, we may make predictions about the characters and events in the story.

2. As you read each paragraph, please write down your reactions to the ideas, images, descriptions of people and places. Try to record any thoughts that come to your mind.

3. Once you have completed the log, re-read the entries. Consider what you wrote within your own cultural background. Can you connect the story to your cultural experiences? Can you see any of your personal fantasies in the story? Did the story encourage you to fantasize about your own life? 